ISSN 0258-7122

Bangladesh J. Agril. Res. 38(4): 579-587, December 2013

\title{
EFFECT OF SPLIT APPLICATION OF NITROGEN FERTILIZER ON YIELD AND YIELD ATTRIBUTES OF TRANSPLANTED AMAN RICE (Oryza sativa L.)
}

\author{
MD. KAMRUZZAMAN ${ }^{1}$, MD. ABDUL KAYUM ${ }^{2}$, MD. MAINUL HASAN ${ }^{2 *}$ \\ MD. MAHMUDUL HASAN ${ }^{3}$, JAIME A. TEIXEIRA DA SILVA ${ }^{4}$
}

\begin{abstract}
Improper doses and splits of nitrogenous fertilizer are two major constraints achieving higher yield of transplanted aman rice in Bangladesh. A field experiment was carried out to study the effect of different levels and split application of nitrogen $(\mathrm{N})$ fertilizer on yield and yield attributes of transplanted aman rice (var. BRRI dhan30). The experiment was laid out in a split-plot design with four split levels of $\mathrm{N}: \mathrm{T}_{1}[1 / 3 \mathrm{~N}$ at basal $+1 / 3 \mathrm{~N}$ at 25 days after transplanting (DAT) $+1 / 3 \mathrm{~N}$ at $50 \mathrm{DAT}], \mathrm{T}_{2}\left[1 \frac{1}{2} \mathrm{~N}\right.$ at $25 \mathrm{DAT}+1 / 2 \mathrm{~N}$ at $\left.50 \mathrm{DAT}\right]$, $\mathrm{T}_{3}[1 / 3 \mathrm{~N}$ at $15 \mathrm{DAT}+1 / 3 \mathrm{~N}$ at $30 \mathrm{DAT}+1 / 3 \mathrm{~N}$ at $45 \mathrm{DAT}], \mathrm{T}_{4}[1 / 4$ at $\mathrm{N} 15 \mathrm{DAT}+$ $1 / 2 \mathrm{~N}$ at $30 \mathrm{DAT}+1 / 4 \mathrm{~N}$ at $45 \mathrm{DAT}]$ in the main plot and four levels of $\mathrm{N}$ in the sub-plot: control (0 kg N/ha), $\mathrm{N}_{1}$ (40 kg N/ha), $\mathrm{N}_{2}$ (80 kg N/ha), and $\mathrm{N}_{3}$ (120 kg $\mathrm{N} / \mathrm{ha}$ ). Data collected were total tillers/hill, effective tillers/hill, number of grains/panicle, grain yield ( $\mathrm{t} / \mathrm{ha}$ ), biological yield ( $\mathrm{t} / \mathrm{ha}$ ) as well as some other morphological characters. Among the $\mathrm{N}$ splits, treatment $\mathrm{T}_{3}$ produced highest total tillers/hill (16.45), effective tillers/hill (12.73), panicle length $(24.97 \mathrm{~cm})$, grains/panicle (127.92), grain yield (5.53 t/ha), biological yield (12.87 t/ha), and harvest index (42.79\%). Among the $\mathrm{N}$ levels, treatment $\mathrm{N}_{3}$ produced highest total tillers/hill (16.50), effective tillers/hill (12.69), grains/panicle (130.36), grain yield (5.40 t/ha), and biological yield (12.66 t/ha). Conversely, the treatment combination of $\mathrm{N}_{3}$ and $\mathrm{T}_{3}$ produced the highest value for most of the traits evaluated, namely total tillers/hill (18.03), effective tillers/hill (14.97), grains/panicle (137.48), grain yield (5.77 t/ha), biological yield (13.08 t/ha), and harvest index (44.10\%). Hence, the treatment combination of $\mathrm{N}_{3}$ and $\mathrm{T}_{3}$ is suggested to bring higher economic benefit from transplanted aman rice in the study area.
\end{abstract}

Keywords: Transplanted aman rice, levels of nitrogen, split application, yield attributes.

\section{Introduction}

Rice (Oryza sativa L.) is the most important cereal crop in the world with more than half of the world's population depending on rice as a staple food, especially

\footnotetext{
${ }^{1}$ Department of Mass Communication, Ministry of Information, Govt. of the People's Republic of Bangladesh, ${ }^{2}$ Department of Agricultural Botany, Patuakhali Science and Technology University, Patuakhali, ${ }^{3}$ The Key Laboratory of Plant-Soil Interactions, China Agricultural University, Beijing, PR China, ${ }^{4}$ Faculty of Agriculture and Graduate School of Agriculture, Kagawa University, Miki-cho, Japan.
} 
in developing countries. It is expected that by 2025, the world will need about 760 million tons of rice in order to meet the demand for the growing population; most arable lands are exploited in Asia, where $90 \%$ of the world's rice is produced and consumed. More than $90 \%$ of the world's rice is grown and consumed in Asia as it is considered as the most important staple food for the people in Asia, and where $60 \%$ of the world's population lives. Rice provides about 35-60\% of the caloric intake of three billion Asians (Guyer et al., 1998). In Bangladesh, only rice contributes $13.05 \%$ to gross domestic product (BBS, 2012). In turns, the national mean yield (2.60 t/ha) of rice in Bangladesh is lower than the potential national yield (5.40 t/ha) and world average rice yield (3.70 t/ha) (Pingali et al., 1997). Two plausible explanations for this disparity are improper fertilizer management and the use of traditional varieties even though the use of high-yielding varieties and judicious application of fertilizer are two of the most effective means for maximizing rice yield. In Bangladesh, during 2009 and 2010, rice covered about 11.34 million ha with an average production of 31.96 million tons among which transplanted aman rice covered 5.66 million ha with a yield of $2.16 \mathrm{t} / \mathrm{ha}$ which is also lower than the national average $(2.60 \mathrm{t} / \mathrm{ha})$. The lower yield of transplanted aman rice has been attributed to several reasons, one of them being poor nitrogen $(\mathrm{N})$ fertilizer management, which is vital as $\mathrm{N}$ fertilizer can increase rice yield by $70-90 \%$ (Win, 2012) proving that rice plants require more $\mathrm{N}$-based nutrients for higher yield. In addition, $\mathrm{N}$ positively influences the production of effective tillers/plant, yield and yield attributes (Islam et al., 2008). Although $\mathrm{N}$ is the major input for rice production, heavy fertilization does not always result in higher yield; moreover, it decreases nitrogen use efficiency (Hasan et al., unpublished data). Selection of the appropriate level of $\mathrm{N}$ fertilizer is a major concern for achieving economic benefit of the crop by decreasing the quantity and increasing nitrogen use efficiency (NUE) while maintaining a sound environment. A rice crop fertilized by $120 \mathrm{~kg} / \mathrm{ha} \mathrm{N}$ showed highest NUE (Baba et al., 2010). Thus, the timely and split application of $\mathrm{N}$ allows for more efficient use of $\mathrm{N}$ by rice throughout the growing season as this practice provides specific amounts of nutrients to the crop during peak periods of growth and reduces $\mathrm{N}$ losses. Two splits of $\mathrm{N}$ before plantation and tillering are commonly practiced at the farmer's level for transplanted aman rice production in Bangladesh. However, the application of $\mathrm{N}$ into three splits at planting, tillering, and panicle initiation stages is most beneficial for achieving higher grain yield of modern rice varieties at medium to high land elevation (Kaushal et al., 2010). Indeed, excessive $\mathrm{N}$ causes vigorous vegetative growth resulting in lodging of plants, increased susceptibility to insects, pests and diseases that ultimately reduces yield. Hence, the present study was conducted to assess the proper dose and split of $\mathrm{N}$ fertilizer application for efficient utilization of $\mathrm{N}$ to achieve higher yield of transplanted aman rice. 


\section{Materials and Method}

The experiment was carried out at the agricultural research farm of Bangladesh Agricultural University, Mymensingh, Bangladesh (24 $21^{\prime} \mathrm{N}$ lat., $88^{\circ} 95^{\prime} \mathrm{E}$ long.) during July to November 2010. The experimental site belongs to the old Brahmaputra flood plain (AEZ-9) consisting primarily of non-calcarious Dark Grey Flood Plain Soil (UNDP and FAO, 1988). The land was sandy loam in texture, flat, well drained, above the flood level and with a $\mathrm{pH}$ of 5.9-6.5. Four levels of $\mathrm{N}$ [control (0 kg N/ha), $\mathrm{N}_{1}$ (40 kg N/ha), $\mathrm{N}_{2}$ (80 kg N/ha) and $\mathrm{N}_{3}(120$ $\mathrm{kg} \mathrm{N} / \mathrm{ha})]$ and four split applications of $\mathrm{N}\left[\mathrm{T}_{1}(1 / 3 \mathrm{~N}\right.$ at basal $+1 / 3 \mathrm{~N}$ at $25 \mathrm{DAT}+$ $1 / 3 \mathrm{~N}$ at $50 \mathrm{DAT}), \mathrm{T}_{2}(1 / 2 \mathrm{~N}$ at $25 \mathrm{DAT}+1 / 2 \mathrm{~N}$ at $50 \mathrm{DAT}), \mathrm{T}_{3}(1 / 3 \mathrm{~N}$ at $15 \mathrm{DAT}+1 / 3$ $\mathrm{N}$ at $30 \mathrm{DAT}+1 / 3 \mathrm{~N}$ at $45 \mathrm{DAT})$ and $\mathrm{T}_{4}(1 / 4$ at $\mathrm{N} 15 \mathrm{DAT}+1 / 2 \mathrm{~N}$ at $30 \mathrm{DAT}+1 / 4 \mathrm{~N}$ at 45 DAT)] were considered as treatments. The trial followed a split-plot design with three replications in which the split application of $\mathrm{N}$ was imposed in the main plot and the level of $\mathrm{N}$ fertilizer made up the sub-plot. A total of 48 unit plots with a unit plot size of $4 \times 2.5=10 \mathrm{~m}^{2}$ were employed and the distance between each main plot was $1.0 \mathrm{~m}$ and that of subplots was $0.5 \mathrm{~m}$. Land preparation involved ploughing, harrowing, and leveling the field to make it suitable for crop establishment by a 4-wheel tractor. Soil was flooded and soaked once with sufficient water to bring the topsoil to saturation and create an overlying water layer. The water depth was $5 \mathrm{~cm}$ but approximately $10 \mathrm{~cm}$ was maintained for about one week after transplanting. Through tillering, a maximum depth of about $3 \mathrm{~cm}$ was maintained. From 30 days before head formation and flowering to the start of maturity, soil was frequently covered with water to a depth of 8 or $10 \mathrm{~cm}$. A continual flow of water was maintained. The field was drained completely 30 to 45 days before harvest to ensure that the field would be dry enough for harvest. The source of nitrogen was commercially produced urea. Triple super phosphate, muriate of potash, gypsum, and zinc sulphate was applied at 100, 70, 60, and $10 \mathrm{~kg} / \mathrm{ha}$, respectively, during final land preparation. Thirty days old seedlings were transplanted from a nursery bed to the main field maintaining 3 seedlings hill $^{-1}$ with a spacing of $20 \times 15 \mathrm{~cm}$. Necessary intercultural operations, such as weeding, irrigation, pest management, etc. were performed accordingly and whenever needed to ensure the growth of a successful crop. Ten hills/plot were randomly uprooted before harvesting in order to collect the following data: total number of tillers/hill, number of effective tillers/hill, panicle length, number of grains/panicle, number of sterile spikelets/panicle, grain yield, biological yield, harvest index (HI). Final data were recorded by averaging 10 values. Data on grain and straw yield/plot were recorded on a plot basis after drying in the sun maintaining $12 \%$ moisture, threshing, winnowing 
and finally converted into ha. The biological yield (grain + straw) was measured and HI was calculated using the following formula (Gardner et al., 1985).

Harvest index $(\%)=\frac{\text { Grain yield }}{\text { Biological yield }(\text { grain }+ \text { straw })} \times 100$

All data was statistically analyzed with the help of MSTAT (Gomez and Gomez, 1984). Analysis of variance (ANOVA) was measured and significant differences between means were calculated by Duncan's multiple range test (DMRT) at $P \leq 0.01$ and 0.05 .

\section{Results and Discussion}

\section{Effect of different levels of nitrogen on rice yield}

The study showed that every morphological and yield-contributing character was positively affected by the increasing levels of $\mathrm{N}$ except panicle length and $\mathrm{HI}$ (Table 1). Total number of tillers/hill and effective number of tillers/hill increased as the rate of $\mathrm{N}$ increased. The highest number of total tillers/hill (16.50) and effective number of tillers/hill (12.69) was recorded when the highest $\mathrm{N}$ level (120 kg N/ha) was applied. The maximum number of effective tillers/hill in rice was found when the rate of $\mathrm{N}$ application was $100 \mathrm{~kg} / \mathrm{ha}$ (Islam et al., 2008). Moreover, the number of grains/panicle (130.36 when the crop was fertilized by $120 \mathrm{~kg} \mathrm{~N} / \mathrm{ha}$; Table 1) was significantly influenced by different levels of nitrogenous fertilizer though panicle length remains insignificant irrespective of the level of $\mathrm{N}$ application. Similar findings were obtained for number of grains/panicle, which increased with an increased rate of $\mathrm{N}$ application up to $120 \mathrm{~kg} \mathrm{~N} / \mathrm{ha}$ (Mandal and Swamy, 2003) and $100 \mathrm{~kg} \mathrm{~N} / \mathrm{ha}$ (Islam et al., 2008). The maximum number of sterile spikelets/panicle (24.80) was recorded when no $\mathrm{N}$ was applied and fewest sterile spikelets/panicle (20.37) formed at 120 $\mathrm{kg} \mathrm{N} / \mathrm{ha}$. Highest grain yield (5.40 t/ha) was obtained when the crop was fertilized by $120 \mathrm{~kg} \mathrm{~N} / \mathrm{ha}$ and the lowest (4.68 t/ha) in the control (Table 1). These results are in partial agreement with Islam et al. (2008) who found maximum number (36) of sterile spikelets/panicle when no nitrogen was applied to the rice field and highest grain yield (2.40 t/ha) in aromatic rice, which was fertilized with a nitrogen of $100 \mathrm{~kg} / \mathrm{ha}$. Maximum biological yield (12.66 t/ha) was obtained when the crop was fertilized with $120 \mathrm{~kg} \mathrm{~N} / \mathrm{ha}$ (Table 1). The application of $\mathrm{N}$ at $150 \mathrm{~kg} / \mathrm{ha}$ resulted in the highest number of total tillers/hill (11.7) (Islam et al., 2008), grains/panicle (109.79) (Salahuddin et al., 2009), grain yield (4.91 t/ha) (Salahuddin et al., 2009), highest biological yield (12.10 t/ha) (Rahman et al., 2007); (6.23 t/ha) (Islam et al., 2008), and lowest number of 
sterile spikelets/panicle (31.4, Islam et al., 2008). When the rice crop was fertilized with $120 \mathrm{~kg} \mathrm{~N} / \mathrm{ha}$, it produced highest grain yield (5.63 t/ha) (Russo, 2012; 4.8 t/ha) Kaushal et al., 2010; 6.1, Baba et al., 2010), while 100 kg N/ha produced highest grain yield (2.23 t/ha), number of total tillers/hill (16.31) as well as lowest number of sterile spikelets/panicle (31.4) (Islam et al., 2008).

Table 1. Effect of nitrogen level on yield and yield characters of BRRI dhan30.

\begin{tabular}{c|c|c|c|c|c|c}
\hline $\begin{array}{c}\text { Level of } \\
\text { nitrogen } \\
\text { (kg N/ha) }\end{array}$ & $\begin{array}{c}\text { Total } \\
\text { tillers/ } \\
\text { hill }\end{array}$ & $\begin{array}{c}\text { Effective } \\
\text { tillers/ } \\
\text { hill }\end{array}$ & $\begin{array}{c}\text { Panicle } \\
\text { length } \\
\text { (cm) }\end{array}$ & $\begin{array}{c}\text { Grains/ } \\
\text { panicle }\end{array}$ & $\begin{array}{c}\text { Sterile } \\
\text { spikelets/ } \\
\text { panicle }\end{array}$ & $\begin{array}{c}\text { Harvest } \\
\text { index } \\
\text { (\%) }\end{array}$ \\
\hline Control & $12.63 \mathrm{c}$ & $8.85 \mathrm{~b}$ & 22.86 & $96.24 \mathrm{~d}$ & $24.80 \mathrm{a}$ & 40.99 \\
$\mathrm{~N}_{1}$ & $14.13 \mathrm{~b}$ & $10.00 \mathrm{~b}$ & 23.64 & $113.34 \mathrm{c}$ & $22.41 \mathrm{~b}$ & 41.93 \\
$\quad \mathrm{~N}_{2}$ & $15.63 \mathrm{a}$ & $11.81 \mathrm{a}$ & 24.04 & $125.54 \mathrm{~b}$ & $21.66 \mathrm{bc}$ & 42.66 \\
$\quad \mathrm{~N}_{3}$ & $16.50 \mathrm{a}$ & $12.69 \mathrm{a}$ & 23.83 & $130.36 \mathrm{a}$ & $20.37 \mathrm{c}$ & 42.57 \\
\hline $\mathrm{Sx}$ & 0.300 & 0.27 & 0.259 & 0.699 & 0.363 & 0.373 \\
$\mathrm{LS}$ & $* *$ & $* *$ & $\mathrm{NS}$ & $* *$ & $* *$ & $\mathrm{NS}$ \\
$\mathrm{CV}(\%)$ & 5.07 & 7.51 & 3.78 & 1.72 & 5.37 & 3.14 \\
\hline
\end{tabular}

In each column, mean with same or without letter do not differ significantly

LS $=$ Level of significance; $*=$ Significant at $P \leq 0.05$, ** $=$ Significant at $P \leq 0.01$, NS $=$ Non significant

$\mathrm{Sx}=$ Standard deviation, $\mathrm{CV}=$ Coefficient of variation

Table 2. Effect of split nitrogen application on yield and yield characters of BRRI dhan30.

\begin{tabular}{|c|c|c|c|c|c|c|}
\hline $\begin{array}{l}\text { Splits of } \\
\text { application of } \\
\text { nitrogen }\end{array}$ & $\begin{array}{l}\text { Total } \\
\text { tiller/ } \\
\text { hill }\end{array}$ & $\begin{array}{l}\text { Effective } \\
\text { tillers/hill }\end{array}$ & $\begin{array}{l}\text { Panicle } \\
\text { length } \\
\text { (cm) }\end{array}$ & $\begin{array}{l}\text { Grains/ } \\
\text { panicle }\end{array}$ & $\begin{array}{l}\text { Sterile } \\
\text { spikelets/ } \\
\text { panicle }\end{array}$ & $\begin{array}{c}\text { Harvest } \\
\text { index } \\
(\%)\end{array}$ \\
\hline $\mathrm{T}_{1}$ & $15.44 \mathrm{~b}$ & $11.32 \mathrm{~b}$ & $23.66 \mathrm{~b}$ & $118.39 \mathrm{~b}$ & $21.72 \mathrm{~b}$ & 42.22 \\
\hline $\mathrm{T}_{2}$ & $12.23 \mathrm{C}$ & 8.83 c & $22.21 \mathrm{c}$ & $103.06 \mathrm{c}$ & 25.06 a & 41.29 \\
\hline $\mathrm{T}_{3}$ & $16.45 \mathrm{a}$ & $12.73 \mathrm{a}$ & $24.97 \mathrm{a}$ & $127.92 \mathrm{a}$ & $20.65 b$ & 42.79 \\
\hline $\mathrm{T}_{4}$ & $14.76 \mathrm{~b}$ & $10.46 \mathrm{~b}$ & $23.54 \mathrm{~b}$ & $116.10 \mathrm{~b}$ & $21.81 \mathrm{~b}$ & 41.85 \\
\hline Sx & 0.215 & 0.235 & 0.257 & 0.577 & 0.346 & 0.381 \\
\hline LS & $* *$ & $* *$ & $* *$ & $* *$ & $* *$ & NS \\
\hline CV(\%) & 5.07 & 7.51 & 3.78 & 1.72 & 5.37 & 3.14 \\
\hline
\end{tabular}

In each column, mean with same or without letter do not differ significantly

LS = Level of significance; $*=$ Significant at $P \leq 0.05$, ** $=$ Significant at $P \leq 0.01, \mathrm{NS}=$

Non significant

$\mathrm{Sx}=$ Standard deviation, $\mathrm{CV}=$ Coefficient of variation 
Table 3. Interaction effect of nitrogen level and split nitrogen application on yield and yield characters of BRRI dhan30.

\begin{tabular}{|c|c|c|c|c|c|c|c|c|}
\hline $\begin{array}{c}\text { Level of N } \\
\times \\
\text { Split of N }\end{array}$ & $\begin{array}{c}\text { Total tillers/ } \\
\text { hill }\end{array}$ & $\begin{array}{l}\text { Effective } \\
\text { tillers/hill }\end{array}$ & $\begin{array}{c}\text { Panicle } \\
\text { length }(\mathrm{cm})\end{array}$ & $\begin{array}{l}\text { Grains/ } \\
\text { panicle }\end{array}$ & $\begin{array}{c}\text { Sterile } \\
\text { spikelets/ } \\
\text { panicle }\end{array}$ & $\begin{array}{l}\text { Grain yield } \\
\text { (t /ha) }\end{array}$ & $\begin{array}{c}\text { Biological } \\
\text { yield } \\
\text { (t/ha) }\end{array}$ & $\begin{array}{c}\text { Harvest } \\
\text { index } \\
(\%)\end{array}$ \\
\hline Control $\times \mathrm{T}_{1}$ & 13.43 & 9.07 & 23.27 & $96.83 \mathrm{j}$ & $24.51 \mathrm{abc}$ & 4.92 & 11.78 & 41.70 \\
\hline Control $\times \mathrm{T}_{2}$ & 10.13 & 7.54 & 21.41 & 82.201 & 26.52 a & 4.23 & 10.64 & 39.72 \\
\hline Control $\times \mathrm{T}_{3}$ & 14.30 & 10.23 & 24.52 & $112.12 \mathrm{i}$ & 23.38 bcd & 5.02 & 11.88 & 42.11 \\
\hline Control $\times \mathrm{T}_{4}$ & 12.63 & 8.55 & 22.24 & $93.82 \mathrm{j}$ & $24.81 \mathrm{ab}$ & 4.55 & 11.24 & 40.43 \\
\hline $\mathrm{N}_{1} \times \mathrm{T}_{1}$ & 14.67 & 10.63 & 23.65 & $120.31 \mathrm{fg}$ & $22.45 \mathrm{~cd}$ & 5.10 & 12.22 & 41.57 \\
\hline $\mathrm{N}_{1} \times \mathrm{T}_{2}$ & 11.20 & 8.19 & 22.38 & 88.85 k & 24.05 bc & 4.65 & 11.17 & 41.65 \\
\hline $\mathrm{N}_{1} \times \mathrm{T}_{3}$ & 16.53 & 11.47 & 25.07 & $128.30 \mathrm{~cd}$ & 21.58 de & 5.60 & 13.20 & 42.48 \\
\hline $\mathrm{N}_{1} \times \mathrm{T}_{4}$ & 14.13 & 9.70 & 23.45 & $115.90 \mathrm{~h}$ & 21.54 de & 5.05 & 11.99 & 42.01 \\
\hline $\mathrm{N}_{2} \times \mathrm{T}_{1}$ & 16.40 & 12.20 & 23.68 & $125.71 \mathrm{de}$ & 21.42 de & 5.27 & 12.26 & 42.88 \\
\hline $\mathrm{N}_{2} \times \mathrm{T}_{2}$ & 13.30 & 9.47 & 22.73 & $117.93 \mathrm{gh}$ & 24.17 bc & 4.76 & 11.19 & 42.52 \\
\hline $\mathrm{N}_{2} \times \mathrm{T}_{3}$ & 16.93 & 14.27 & 25.28 & 133.78 b & 17.72 g & 5.73 & 13.30 & 42.47 \\
\hline $\mathrm{N}_{2} \times \mathrm{T}_{4}$ & 15.87 & 11.30 & 24.46 & $124.75 \mathrm{e}$ & 23.35 bcd & 5.13 & 12.00 & 42.77 \\
\hline $\mathrm{N}_{3} \times \mathrm{T}_{1}$ & 17.27 & 13.37 & 24.00 & 130.72 bc & $18.48 \mathrm{fg}$ & 5.50 & 12.87 & 42.74 \\
\hline $\mathrm{N}_{3} \times \mathrm{T}_{2}$ & 14.30 & 10.11 & 22.33 & 123.27 ef & $25.52 \mathrm{ab}$ & 4.91 & 11.91 & 41.26 \\
\hline $\mathrm{N}_{3} \times \mathrm{T}_{3}$ & 18.03 & 14.97 & 25.00 & 137.48 a & 19.93 ef & 5.77 & 13.08 & 44.10 \\
\hline $\mathrm{N}_{3} \times \mathrm{T}_{4}$ & 16.40 & 12.30 & 24.00 & 129.95 c & $17.55 \mathrm{~g}$ & 5.40 & 12.80 & 42.19 \\
\hline Sx & 0.431 & 0.469 & 0.515 & 1.154 & 0.691 & 0.271 & 0.539 & 0.761 \\
\hline LS & NS & NS & NS & $* *$ & $* *$ & NS & NS & NS \\
\hline CV (\%) & 5.07 & 7.51 & 3.78 & 1.72 & 5.37 & 9.21 & 7.71 & 3.14 \\
\hline
\end{tabular}

In each column, mean with same or without letter do not differ significantly.

LS = Level of significance $* *=$ Significant at $P \leq 0.01, \mathrm{NS}=$ Non-significant.

$\mathrm{Sx}=$ Standard deviation, $\mathrm{CV}=$ Coefficient of variation. 


\section{Effect of split application of nitrogen on rice yield}

The split application of $\mathrm{N}$ had a significant effect on all yield attributing parameters except for HI (Table 2). The highest number of total tillers/hill (16.45), number of effective tillers/hill (12.73), panicle length $(24.97 \mathrm{~cm})$, number of grains/panicle (127.92), biological yield (12.87 t/ha), and HI (42.79\%) were noted when $\mathrm{N}$ was applied in three equal splits, $1 / 3$ at $15 \mathrm{DAT}+1 / 3$ at 30 DAT $+1 / 3$ at 45 DAT (Table 2). $\mathrm{N}$ ap plication in three sp lits gave the $h$ igh est number of tillers/hill (25.11); (Islam et al., 2009), panicle length (25.9), (Kaushal et al., 2010 (20.1), (Hasanuzzaman et al., 2009), grains/panicle (124), (Kaushal et al., 2010), and biological yield (11.99 t/ha; Kaushal et al., 2010), identical to other findings (Hirzel et al., 2011). Highest grain yield (5.53 t/ha) was obtained when $N$ was applied in three equal splits viz., $1 / 3$ at 15 DAT $+1 / 3$ at 30 DAT $+1 / 3$ at $45 \mathrm{DAT}$ and the lowest (4.64 t/ha) was noted when $\mathrm{N}$ was applied in two splits, viz. $1 / 2$ at 25 DAT $+1 / 2$ at 50 DAT (Table 2), which is in agreement with the findings of Kaushal et al. (2010) who found highest productive tillers $/ \mathrm{m}^{-2}$ (76), panicle length $(26 \mathrm{~cm})$, grain yield (4.2 t/ha), and biological yield ( $9.5 \mathrm{t} / \mathrm{ha})$ from three splits of $N$ viz., $1 / 2$ basal, $1 / 4$ at tillering, and $1 / 4$ at panicle initiation. The variation in results caused by the same number of splits might be due to different locations and environments. The highest number of sterile spiketets/panicle (25.06) was found in two splits of $\mathrm{N}$ viz., $1 / 2 \mathrm{~N}$ at $25 \mathrm{DAT}+1 / 2 \mathrm{~N}$ at 50 DAT (Table 2) indicates that the $\mathrm{N}$ requirement of aman rice is dependent on quantity and varies with the growth stage.

\section{Interaction effect of different levels and split application of $\mathrm{N}$ on rice yield}

$\mathrm{N}_{3}(120 \mathrm{~kg} \mathrm{~N} / \mathrm{ha})$ gave the highest grain yield (5.77 t/ha) when splited as $T_{3}(1 / 3$ at $15 \mathrm{DAT}+1 / 3$ at $30 \mathrm{DAT}+1 / 3$ at $45 \mathrm{DAT}$ ) (Table 3 ). The control $(0 \mathrm{~kg} \mathrm{~N} / \mathrm{ha}$ ) gave lowest grain yield (4.23 t/ha) with a split application of $T_{2}(1 / 2$ at 25 DAT $+1 / 2$ at 50 DAT). Biological yield followed a similar trend as grain yield. The combination of $\mathrm{N}_{3}$ and $\mathrm{T}_{3}$ gave the highest number of total tillers/hill (18.03), number of effective tillers/hill (14.97), number of grains/panicle (137.48), and HI (44.10\%). The highest number of sterile spikelets/panicle (26.52) was recorded in the control. The lowest number of sterile spikelets/panicle (17.55) was recorded in the $\mathrm{N}_{3} \mathrm{~T}_{4}$ combination, which was statistically identical to the $\mathrm{N}_{3} \mathrm{~T}_{3}$ and $\mathrm{N}_{3} \mathrm{~T}_{1}$ interactions.

\section{Conclusion}

The results revealed that application of $120 \mathrm{~kg}$ N/ha produced highest number of tillers/hill, grain and straw yield. However, among the split applications, the highest grain and straw yield was obtained from three equal splits of $\mathrm{N}$, i.e., $1 / 3$ at 15 DAT $+1 / 3$ at 30 DAT $+1 / 3$ at 45 DAT. In case of interaction effect of different 
levels and split application of $\mathrm{N}$, highest grain yield was obtained from treatment $120 \mathrm{~kg} \mathrm{~N} /$ ha combined with three equal splits i.e., $1 / 3$ at $15 \mathrm{DAT}+1 / 3$ at $30 \mathrm{DAT}+$ $1 / 3$ at 45 DAT. Hence, for higher grain yield of transplanted aman rice, N fertilization at $120 \mathrm{~kg} / \mathrm{ha}$ should be applied in three equal splits viz., $1 / 3$ at $15 \mathrm{DAT}$ $+1 / 3$ at $30 \mathrm{DAT}+1 / 3$ at 45 DAT.

\section{References}

Baba, H., S. S. Hussain, A. Kumar, and F. A. Misger. 2010. Influence of nitrogen levels and bio-fertilizers on uptake, use efficiency and build up of nitrogen under rice crop. Res. J. Agril. Sci. 1(4): 375-379.

BBS. 2012. Agricultural Census in Bangladesh. Bangladesh Bureau of Statistics, Agriculture Wing. Website: http://www.bbs.gov.bd - Accessed on September 29, 2012.

Gardner, F. P., R. B. Pearce, and R. L. Mitchell. 1985. Physiology of Crop Plants. 1st Edn., The Iowa State University Press, Ames, Iowa. P 478.

Gomez, K. A. and A. K. Gomez. 1984. Statistical procedures for Agricultural Research. $2^{\text {nd }}$ Edn. John. Wiley and Sons. P 207-215.

Guyer, D., A. Tuttle, S. Rouse, S. Volrath, M. Johnson, S. Potter, J. Gorlach, S. Goff, L. Crossland and E. Ward. 1998. Activation of latent 171 transgenes in arabidoppsis using a hybrid transcription factor. Genetics 149: 633-639.

Hasanuzzaman, M., K. Nahar, M. M. Alam, M. Z. Hossain, and M. R. Islam. 2009. Response of transplanted rice to different application methods of urea fertilizer. Int. J. Sustain. Agric. 1 (1): 01-05.

Hirzel, J., A. Pedreros and K Cordero. 2011. Effect of nitrogen rates and split nitrogen fertilization on grain yield and its components in flooded rice. Chilean J. Agril. Res. 71(3): 437-444.

Islam, M. S., M. A. Hossain, M. A. H. Chowdhury, M. A. Hannan. 2008. Effect of nitrogen and transplanting date on yield and yield components of aromatic rice. $J$. Bangladesh Agril. Univ. 6(2): 291-296.

Islam, M. S., M. Hasanuzzaman, M. Rokonuzzaman K. Nahar. 2009. Effect of split application of nitrogen fertilizer on morphophysiological parameters of rice genotypes. Intl. J. Plant Prod. 3(1): 51-61.

Kaushal, A. K., N. S. Rana, A. Singh, Sachin, Neeraj, and A. Srivastav. 2010. Response of levels and split application of nitrogen in green manured wetland rice (Oryza sativa L.). Asian J. Agril. Sci. 2(2):42-46.

Mandal, S. and S. N. Swamy. 2003. Effect of time of nitrogen application on yield and yield attributes of rice (Oryza sativa) cultivars. Environ. Ecol. 21(2): 411-413.

Pingali, P. L., M. Hossain and R. V. Gerpacio. 1997. The Asian rice bowls: The returning crisis? CAB International, London, and IRRI, MCPO box 3217, Makati 1271, Philippines. 
Rahman, M. H., M. H. Ali, M. M. Ali, and M. M. Khatun. 2007. Effect of different levels of nitrogen on growth and yield of transplant aman rice cV BRRI dhan32. Int. J. Sustain Crop Prod. 2(1), 28-34.

Russo, S. 2012. Rice yield as affected by the split method of $\mathrm{N}$ application and nitrification inhibitor DCD. http://ressources.ciheam.org/om/pdf/ c15-1/CI010955. pdf. Accessed on September 29, 2012.

Salahuddin, K. M., S. H. Chowhdury, S. Munira, M. M. Islam, and S. Parvin. 2009. Response of nitrogen and plant spacing of transplanted aman rice. Bangladesh $\mathrm{J}$. Agril. Res. 34(2): 279-285.

Sathiya, K. and T. Ramesh. 2009. Effect of split application of nitrogen on growth and yield of aerobic rice. Asian J. Exp. Sci. 23 (1): 303-306.

UNDP and FAO. 1988. Land resources appraisal of Bangladesh for Agricultural Development Report No. 2. Agro-ecological Regions of Bangladesh. United Nations Development Programme and Food and Agricultural Organization. Rome. P. 212221.

Win, K. K. 2012. Plot specific N fertilizer management for improved N-use efficiency in rice based system of Bangladesh. http://www.zef.de/fileadmin/webfiles/ downloads/zefc_ecology_development/ecol_dev__12_Win_text.pdf. Accessed on September 29, 2012. 